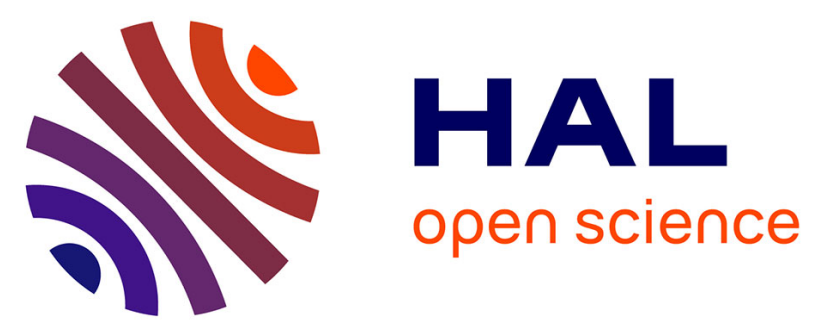

\title{
Late-onset cervicoscapular muscle atrophy and weakness after radiotherapy for Hodgkin's disease: a case series
}

Alain Furby, Anthony Behin, Jean-Pascal Le Faucheur, Katell Beauvais, Pascale Marcorelles, Jean-Marie Mussini, Guillaume Bassez, Bruno Eymard, Isabelle Penisson

\section{To cite this version:}

Alain Furby, Anthony Behin, Jean-Pascal Le Faucheur, Katell Beauvais, Pascale Marcorelles, et al.. Late-onset cervicoscapular muscle atrophy and weakness after radiotherapy for Hodgkin's disease: a case series. Journal of Neurology, Neurosurgery and Psychiatry, 2009, 81 (1), pp.101. 10.1136/jnnp.2008.167577 . hal-00552743

\section{HAL Id: hal-00552743 \\ https://hal.science/hal-00552743}

Submitted on 6 Jan 2011

HAL is a multi-disciplinary open access archive for the deposit and dissemination of scientific research documents, whether they are published or not. The documents may come from teaching and research institutions in France or abroad, or from public or private research centers.
L'archive ouverte pluridisciplinaire HAL, est destinée au dépôt et à la diffusion de documents scientifiques de niveau recherche, publiés ou non, émanant des établissements d'enseignement et de recherche français ou étrangers, des laboratoires publics ou privés. 


\title{
Late-onset cervicoscapular muscle atrophy and weakness after radiotherapy for Hodgkin's disease: a case series
}

\author{
Alain Furby ${ }^{\mathrm{a}}$, Anthony Béhin ${ }^{\mathrm{b}}$, Jean-Pascal Lefaucheur ${ }^{\mathrm{c}}$, Katell Beauvais ${ }^{\mathrm{a}}$, Pascale \\ Marcorelles $^{\mathrm{d}}$, Jean-Marie Mussini ${ }^{\mathrm{e}}$, Guillaume Bassez ${ }^{\mathrm{c}}$, Alain Créange ${ }^{\mathrm{c}}$, \\ Bruno Eymard $^{\mathrm{b}}$, Isabelle Pénisson-Besnier ${ }^{\mathrm{e}}$
}

${ }^{\text {a } U n i t e ́ ~ d e ~ N e u r o p h y s i o l o g i e ~ C l i n i q u e, ~ H o ̂ p i t a l ~ Y v e s ~ L e ~ F o l l, ~ S a i n t-B r i e u c, ~ F r a n c e ~}$

${ }^{\mathrm{b}}$ Centre de référence des maladies rares neuromusculaires, APHP, GH Pitié-Salpêtrière, Paris, France

${ }^{\mathrm{c}}$ Centre de référence des maladies rares neuromusculaires, APHP, GH Henri Mondor - Albert Chenevier, Créteil, France

${ }^{\mathrm{d}}$ Pôle de Biologie Pathologie, Hôpital Morvan, CHU Brest, France

${ }^{\mathrm{e}}$ Centre de référence des maladies neuromusculaires Nantes-Angers, CHU d'Angers et Nantes, France

Proofs and reprint should be sent to Dr Alain Furby, Unité de Neurophysiologie Clinique, Hôpital Yves Le Foll, 22027 Saint-Brieuc, France. 


\begin{abstract}
Patients with cervical or mediastinal Hodgkin's disease (HD) classically underwent chemotherapy plus extended-field radiation therapy. We report six patients who gradually developed severe atrophy and weakness of cervical paraspinal and shoulder girdle muscles five to 30 years after mantle irradiation for HD. Although clinical presentation was uniform, including a dropped head syndrome, electrophysiological and pathological findings were rather heterogeneous. Either neurogenic or myogenic processes may be involved and sometimes combined. We discuss the pathophysiological mechanisms underlying these cervico-scapular motor complications of mantle irradiation in HD.
\end{abstract}

\title{
Key Words
}

Complication of radiation therapy, dropped head syndrome, Hodgkin's disease, mantle irradiation, muscle atrophy, myopathy.

\section{5 words}




\section{Introduction}

The classical treatment of Hodgkin's disease (HD) is based on chemotherapy plus radiation therapy (RT). ${ }^{1-3}$ Late neurological adverse events after extended-field RT include brachial or lumbar plexopathy ${ }^{4,5}$ and chronic progressive myelopathy. ${ }^{6}$ A few patients were found to develop severe weakness and atrophy of cervical and shoulder girdle musculature that developed several years after mantle irradiation. ${ }^{7-10}$ The clinical presentation usually includes a dropped head syndrome. The pathophysiology of this rare post-RT complication is still unclear. In this study we report detailed clinical, electrophysiological and pathological findings in six original cases sharing the same condition of late-onset cervicoscapular muscle atrophy and weakness following mantle irradiation for HD.

\section{Case reports}

The six patients had a medical history of HD (stage I to stage III) treated by chemotherapy followed by extended-field RT, including mantle irradiation, and were considered to be in complete remission. Details are given in table 1.

They all were referred for weakness and atrophy of cervical paraspinal and shoulder girdle musculature. The mean delay between irradiation and first symptoms was 19.7 years (ranged from five to 30). Neck pain was reported by four patients. Patients did not complain of cramps, fasciculations, myokimia, or any other abnormal spontaneous muscle activity, as well as of any sensory deficit.

Clinical examination showed severe weakness and atrophy of splenius capitis, supraspinatus, infraspinatus, trapezius, sternocleidomastoid and deltoid muscles, leading to a dropped head syndrome in four cases (Fig.1). Cranial nerves were normal and patients had neither swallowing difficulties nor dysarthria. Stretch reflexes and sensory examination were 
normal, except a symmetrical, distal hypoesthesia in the lower limbs (with absent achillean stretch reflexes) attributed to diabetic polyneuropathy in patient No 3.

Laboratory investigation was unremarkable in all patients, regarding blood cell count, electrolyte dosage, $\mathrm{C}$ reactive protein, serum protein immunoelectrophoresis, thyroid function test, and serologies for human immunodeficiency virus 1 and 2, and $\mathrm{B}$ and $\mathrm{C}$ hepatitis virus. Serum creatin kinase level was slightly elevated in four cases (mean $=395 \mathrm{UI} / \mathrm{l}$ ). Cerebral spinal fluid examination showed elevated protein concentration $(0.71 \mathrm{~g} / 1)$ in one patient and was normal in 2 others. Cervical spinal magnetic resonance imaging and whole-body positron emission tomography for lymph node and metastatic examination disclosed no abnormalities. Cervical computed tomography scan performed in 3 patients revealed diffuse muscle atrophy with fatty changes in paraspinal muscles.

In all the patients, weakness may have progressed but did not extend beyond the initially involved muscle groups over several years (one to nine years). Treatment by oral steroids $(1 \mathrm{mg} / \mathrm{kg})$ was administered for three months in one patient $\left(\mathrm{N}^{\circ} 2\right)$, without any clinical benefit. 
Table 1

\begin{tabular}{|c|c|c|c|c|c|c|c|c|c|}
\hline $\begin{array}{l}\text { Patient No } \\
\text { sex, age at } \\
\text { presentation } \\
\text { (years) }\end{array}$ & Chemotherapy & RT protocol & $\begin{array}{c}\text { Extra- } \\
\text { neurological } \\
\text { complications of } \\
\text { RT }\end{array}$ & $\begin{array}{c}\text { Interval } \\
\text { between RT } \\
\text { and weakness } \\
\text { (years) }\end{array}$ & $\begin{array}{c}\text { Muscle weakness and } \\
\text { wasting }\end{array}$ & $\begin{array}{c}\text { CK } \\
(\mathrm{N}<180 \\
\mathrm{UI} / \mathbf{l})\end{array}$ & Needle EMG pattern & Muscle CT findings & $\begin{array}{l}\text { Muscle biopsy } \\
\text { characteristics }\end{array}$ \\
\hline $\begin{array}{c}1 \\
\mathrm{M}, 51\end{array}$ & $\begin{array}{l}\text { MOPP and then } \\
\text { ABVD one year } \\
\text { later for bone } \\
\text { relapse }\end{array}$ & $\begin{array}{l}\text { MF, lomboaortic, } \\
\text { splenic areas. } \\
40 \text { Gy in } 20 \\
\text { fractions }\end{array}$ & Hypothyroidism & 8 & $\begin{array}{l}\text { Cervical paraspinal, } \\
\text { supraspinatus, } \\
\text { infraspinatus, deltoid }\end{array}$ & $\mathrm{N}$ & $\begin{array}{l}\text { Myopathic findings in cervical } \\
\text { paraspinal and deltoid muscles }\end{array}$ & $\begin{array}{l}\text { Atrophy of cervical } \\
\text { paraspinal and deltoid } \\
\text { muscles }\end{array}$ & $\begin{array}{l}\text { Mild fiber size variation, } \\
\text { type } 1 \text { predominance }\end{array}$ \\
\hline $\begin{array}{c}2 \\
F, 37\end{array}$ & ABVD & $\begin{array}{l}\text { MF with sparing } \\
\text { of axillae, T11- } \\
\text { L3 and splenic } \\
\text { areas. } \\
40 \text { Gy then } 30 \text { Gy } \\
2 \text { months later }\end{array}$ & $\begin{array}{l}\text { Neck erythema, } \\
\text { hypothyroidism, } \\
\text { telangiectasia on } \\
\text { the upper part of } \\
\text { the trunk }\end{array}$ & 5 & $\begin{array}{l}\text { Anterior and posterior } \\
\text { cervical and thoracic } \\
\text { paraspinal, trapezius, } \\
\text { supraspinatus, deltoid, } \\
\text { dropped head syndrome }\end{array}$ & 270 & $\begin{array}{l}\text { Fibrillation at rest, neurogenic } \\
\text { and myopathic findings in } \\
\text { cervico-thoracic paraspinal } \\
\text { muscles }\end{array}$ & $\begin{array}{l}\text { Fatty changes in } \\
\text { cervico-thoracic } \\
\text { paraspinal muscles }\end{array}$ & $\begin{array}{c}\text { Hypertrophic and } \\
\text { atrophic fibers, } \\
\text { disorganized architecture } \\
\text { in many fibers, } \\
\text { internalized myonuclei. } \\
\text { increased endomysial } \\
\text { connective tissue. }\end{array}$ \\
\hline $\begin{array}{c}3 \\
F, 69\end{array}$ & MOPP & $\begin{array}{c}\text { MF. } \\
\text { About } 40 \text { Gy in } \\
21 \text { fractions }\end{array}$ & $\begin{array}{c}\text { Gastric } \\
\text { lymphoma, type } \\
2 \text { diabetes }\end{array}$ & 24 & $\begin{array}{c}\text { Posterior cervical } \\
\text { paraspinal, } \\
\text { sternocleidomastoid, } \\
\text { supraspinatus, } \\
\text { infraspinatus, deltoid, } \\
\text { dropped head syndrome }\end{array}$ & 299 & $\begin{array}{l}\text { Complex repetitive discharges } \\
\text { at rest in sternocleidomastoid. } \\
\text { Neurogenic and myopathic } \\
\text { findings in } \\
\text { sternocleidomastoid, upper } \\
\text { trapezius, infraspinatus, and } \\
\text { deltoid muscles }\end{array}$ & $\begin{array}{l}\text { Atrophy of cervical } \\
\text { paraspinal muscles }\end{array}$ & $\begin{array}{l}\text { Lobulated fibers on } \\
\text { oxidative stainings }\end{array}$ \\
\hline
\end{tabular}




\begin{tabular}{|c|c|c|c|c|c|c|c|c|c|}
\hline $\begin{array}{c}4 \\
F, 56\end{array}$ & MOPP & $\begin{array}{l}\text { MF sparing } \\
\text { axillae. } \\
36 \text { Gy in } 16 \\
\text { fractions }\end{array}$ & $\begin{array}{c}\text { Hypothyroidism, } \\
\text { constrictive } \\
\text { pericarditis }\end{array}$ & 23 & $\begin{array}{l}\text { Posterior cervical, } \\
\text { trapezius, supraspinatus, } \\
\text { dropped head syndrome }\end{array}$ & $\mathrm{N}$ & $\begin{array}{l}\text { Complex repetitive discharges } \\
\text { at rest in upper trapezius. } \\
\text { Neurogenic findings in } \\
\text { splenius capitis, upper } \\
\text { trapezius, and supraspinatus } \\
\text { muscles }\end{array}$ & ND & ND \\
\hline $\begin{array}{c}5 \\
\text { M, } 58\end{array}$ & MOPP & $\begin{array}{c}\text { MF, lomboaortic, } \\
\text { splenic areas. } \\
40 \mathrm{~Gy}\end{array}$ & $\begin{array}{l}\text { Eight episodes of } \\
\text { severe digestive } \\
\text { obstruction due } \\
\text { to radiation } \\
\text { enteritis }\end{array}$ & 30 & $\begin{array}{c}\text { Sternocleidomastoid, } \\
\text { trapezius, supraspinatus, } \\
\text { infraspinatus }\end{array}$ & 554 & $\begin{array}{l}\text { Neurogenic findings in upper } \\
\text { trapezius, supraspinatus, and } \\
\text { infraspinatus muscles }\end{array}$ & ND & ND \\
\hline $\begin{array}{c}6 \\
M, 44\end{array}$ & MOPP & $\begin{array}{l}\text { MF. } \\
36 \mathrm{~Gy}\end{array}$ & None & 28 & $\begin{array}{c}\text { Posterior cervical, } \\
\text { supraspinatus, } \\
\text { infraspinatus, deltoid, } \\
\text { dropped head syndrome }\end{array}$ & 458 & $\begin{array}{l}\text { No abnormalities in examined } \\
\text { muscles }\end{array}$ & ND & $\begin{array}{l}\text { Mild fiber size variation, } \\
\text { internal nuclei, irregular } \\
\text { inter-myofibrillar pattern }\end{array}$ \\
\hline
\end{tabular}




\section{Electrophysiological data}

Nerve conduction studies were normal in the four limbs, including no proximal conduction block or any sign of demyelinating neuropathy. A reduction of compound muscle action potential amplitude in upper trapezius muscle to spinal nerve stimulation was observed in patient $\mathrm{N}^{\circ}$ 3. Needle electromyography (EMG) showed abnormal muscle activity at rest (fibrillation potentials or complex repetitive discharges) in three patients $\left(\mathrm{N}^{\circ} 2,3,4\right)$. During contraction, myopathic EMG findings (motor unit potentials (MUPs) of reduced amplitude and duration) were found in paraspinal and deltoid muscles in one patient $\left(\mathrm{N}^{\circ} 1\right)$. Two patients $\left(\mathrm{N}^{\circ} 4,5\right)$ showed neurogenic EMG changes in splenius capitis, upper trapezius, supraspinatus and infraspinatus muscles. A combination of myopathic MUPs with neurogenic recruitment was predominantly found in paraspinal, neck and deltoid muscles in two patients $\left(\mathrm{N}^{\circ} 2,3\right)$. In the last patient $\left(\mathrm{N}^{\circ} 6\right)$, needle EMG remained normal, but the examination was incomplete and did not study the most affected muscles.

\section{Pathological studies}

A biopsy of the deltoid muscle was performed in the four patients in whom this muscle was clinically affected by wasting and weakness (see Table 1). Variation in muscle fiber size was mild in two patients $\left(\mathrm{N}^{\circ} 1,6\right)$ and more pronounced in one patient $\left(\mathrm{N}^{\circ} 2\right)$, with a combination of hypertrophic and atrophic fibers from one sample to another (Fig. 1). A few nuclear clumps were observed. Many fibers had a markedly disorganized architecture: some were split; others had a whorled or annular aspect. A moderate increase in the number of internalized myonuclei was found. Endomysial connective tissue was slightly increased, and some areas were infiltrated by adipocytes. Some samples showed a predominance of muscle fibers of type 1 . We did not find type grouping, target/targetoid changes, necrotic fibers, inflammatory 
infiltrates, rods or amyloid deposits. Blood vessels were unremarkable. Immunostaining for dystrophin, sarco- and dystroglycans, dysferlin and caveolin was negative.

\section{Discussion}

In 1998, Johansson et al. ${ }^{7}$ first pointed out that neck and shoulder girdle muscles could present wasting and weakness in long-term HD survivors as a late complication of mantle irradiation. The following report was that of Portlock et al. ${ }^{8}$ who described histological features of nemaline myopathy in trapezius muscle of a patient who had undergone mantle irradiation for HD 16 years before. Additional cases of dropped head syndrome occurring as a late complication of mantle irradiation for HD were reported in one paper $(3 \text { cases })^{9}$ and an abstract ( 4 cases). ${ }^{10}$

The common clinical feature in all these patients, including our six patients, was a severe wasting confined to neck and shoulder girdle musculature, leading to a dropped head syndrome in most cases. It develops as a pure motor syndrome without clinical sensory manifestations, except cervical pain that preceded weakness by several months or years in some patients. Contracture of anterior cervical muscles was also described, ${ }^{9}$ but not observed in our patients. Absence of paresthesias, hypesthesia, or sensory nerve conduction abnormalities and preserved stretch reflexes can rule out the hypothesis of a plexopathy, another rare complication of mantle irradiation. ${ }^{4,11}$

The pathophysiology of cervico-scapular muscle weakness and wasting following mantle irradiation in HD could result from primary muscle damage or anterior horn or root lesions at upper cervical level. In the present series, EMG changes were myopathic in one patient, neurogenic in two patients and included a combination of myopathic MUPs with neurogenic recruitment in two others. In the literature, both myopathic and neurogenic EMG alterations have also been reported. ${ }^{9}$ Regarding histopathological studies, the abnormalities 
were non-specific in the four patients in whom we performed muscle biopsy, but they were more in line with predominant non-inflammatory myopathic changes. Such a finding has been previously reported, ${ }^{10}$ as well as the presence of rod/nemaline bodies ${ }^{8}$ or features of muscle denervation. $^{9}$

Both myopathic and neurogenic processes may underlie the pathophysiological changes, because cervico-scapular muscles are located within the field of mantle irradiation as well as upper cervical anterior horns and roots. In addition, the potential neuromuscular toxicity of chemotherapeutic drugs could play a sensitization role. However, myopathic and neurogenic processes may be not equally involved in all patients and territories. Following our observations, myopathic features seemed to be predominant regarding histopathological findings in deltoid muscles, while definite neurogenic signs could be found in needle EMG examination of neck and paraspinal muscles. Nevertheless, myopathic alterations were clearly predominant in three patients of this series.

Irradiation has been considered to cause relatively little or no direct damage to mature muscle fibers and in fact myositis is an infrequently reported adverse effect of RT. ${ }^{12}$ However, high radiation doses are known to dramatically alter the proliferation of muscle precursor cells and were used in experimental animal models to inhibit spontaneous muscle regeneration. ${ }^{13}$ Fajardo et al. ${ }^{14}$ hypothesized that radiation could induce primarily vascular lesions due to high susceptibility to radiation of capillaries and vessels. These lesions may result from an imbalance in the cross talk between endothelial cells and vascular smooth muscle cells. ${ }^{15}$ A secondary increase in collagen content and a proliferation of fibrous tissue may occur in the irradiated tissue, ${ }^{16}$ leading to progressive deterioration over several years following RT. These processes are delayed, evolving many years after RT completion and they are generally dose-and time-dependent. 
In conclusion, clinicians should be aware that weakness and wasting can occur in neck and shoulder girdle musculature of long-term HD survivors who had previously undergone mantle irradiation. Whatever the underlying pathophysiology, the lesions appear to be irreversible as other delayed complications of RT. This observation supports the current development of involved-field RT protocols based on limited rather than extended fields of irradiation to reduce the risk of late complications.

\section{References}

1. Hoppe RT. Hodgkin's lymphoma: the role of radiation in the modern combined strategies of treatment. Hematol Oncol Clin North Am 2007;21:915-27.

2. Liao Z, Ha CS, Vlachaki MT, et al. Mantle irradiation alone for pathologic stage I and II Hodgkin's disease: long-term follow-up and patterns of failure. Int J Radiat Oncol Biol Phys 2001;50:971-7.

3. Glossmann JP, Josting A, Diehl V. New treatments for Hodgkin's disease. Curr Treat Options Oncol 2002;3:283-90.

4. Wadd NJ, Lucraft HH. Brachial plexus neuropathy following mantle radiotherapy. Clin Oncol (R Coll Radiol) 1998;10:399-400.

5. Malow BA, Dawson DM, Neuralgic amyotrophy in association with radiation therapy for Hodgkin's disease. Neurology 1991,41:440-1.

6. Béhin A, Delattre JY. Complications of radiation therapy on the brain and spinal cord. Semin Neurol 2004;24:405-17.

7. Johansson AS, Erlanson M, Lenner P, Lindh J, Osterman B. Late side-effects are common after treatment of Hodgkin's disease. Muscular atrophy following radiotherapy is a neglected risk. Lakartidningen 1998;95:44-7. 
8. Portlock CS, Boland P, Hays AP, Antonescu CR, Rosenblum MK. Nemaline myopathy: a possible late complication of Hodgkin's disease therapy. Hum Pathol 2003;34:816-8.

9. Rowin J, Cheng G, Lewis SL, Meriggioli MN. Late appearance of dropped head syndrome after radiotherapy for Hodgkin's disease. Muscle Nerve 2006;34:666-9.

10. Aggarwal S, Amato A. Radiation induced myopathy following mantle field radiation for hodgkin's disease: a report of 4 cases. Neurology 2007;68 (suppl 1):P05.107.

11. Churn M, Clough V, Slater A. Early onset of bilateral brachial plexopathy during mantle radiotherapy for Hodgkin's disease. Clin Oncol (R Coll Radiol) 2000;12:289-91.

12. Welsh JS, Torre TG, DeWeese TL, O'Reilly S. Radiation myositis. Ann Oncol 1999;10:1105-8.

13. Alameddine HS, Dehaupas M, Fardeau M. Regeneration of skeletal muscle fibers from autologous satellite cells multiplied in vitro. An experimental model for testing cultured cell myogenicity. Muscle Nerve 1989;12:544-55.

14. Fajardo LF, Berthrong M. Vascular lesions following radiation. Pathol Annu 1988;23:297-330.

15. Milliat F, François A, Isoir M, et al. Influence of endothelial cells on vascular smooth muscle cells phenotype after irradiation: implication in radiation-induced vascular damages. Am J Pathol 2006;169:1484-95.

16. Wegrowski J, Lafuma C, Lefaix JL, Daburon F, Robert L. Modification of collagen and noncollagenous proteins in radiation-induced muscular fibrosis. Exp Mol Pathol 1988;48:273-85. 


\section{Legends of figure and table}

Figure 1. A. Clinical presentation (patient $\mathrm{N}^{\circ} 6$ ): severe wasting of cervicoscapular muscles following radiation therapy for Hodgkin's disease. B, C. Deltoid muscle biopsy (patient $\mathrm{N}^{\circ} 2$ ): marked fiber size variation, increased interstitial fat and connective tissue, and numerous structural changes (many whorled fibers). Hematoxylin and eosin (B) and ATPase pH 9.4 (C) staining, magnitude 200X. Informed consent was obtained for publication of this figure.

Table 1: Clinical characteristics, electrophysiological, imaging, and pathological findings. ABVD: doxorubicin, bleomycin, vinblastine, and dacarbazine; $\mathrm{CK}$ : creatin kinase plasma level; CT: computed tomography scan; EMG: needle electromyography; MF: mantle field irradiation; MOPP: Mustargen, Oncovin, Procarbazine, Prednisone; ND: not done; RT: radiation therapy.

Acknowledgements: The authors are grateful to Dr Pierre Bouche, GH Pitié-Salpêtrière, Paris, and Dr Grégory Taurin, CH Saint-Malo, for their collaboration and support in patient care.

\section{Competing interests: none}

"the Corresponding Author has the right to grant on behalf of all authors and does grant on behalf of all authors, an exclusive licence (or non exclusive for government employees) on a worldwide basis to the BMJ Publishing Group Ltd and its Licensees to permit this article (if accepted) to be published in the Journal of Neurology, Neurosurgery \& Psychiatry editions and any other BMJPGL products to exploit all subsidiary rights, as set out in our licence (http://jnnp .bmjjournals.com/ifora/licence.pdf)." 
Figure 1

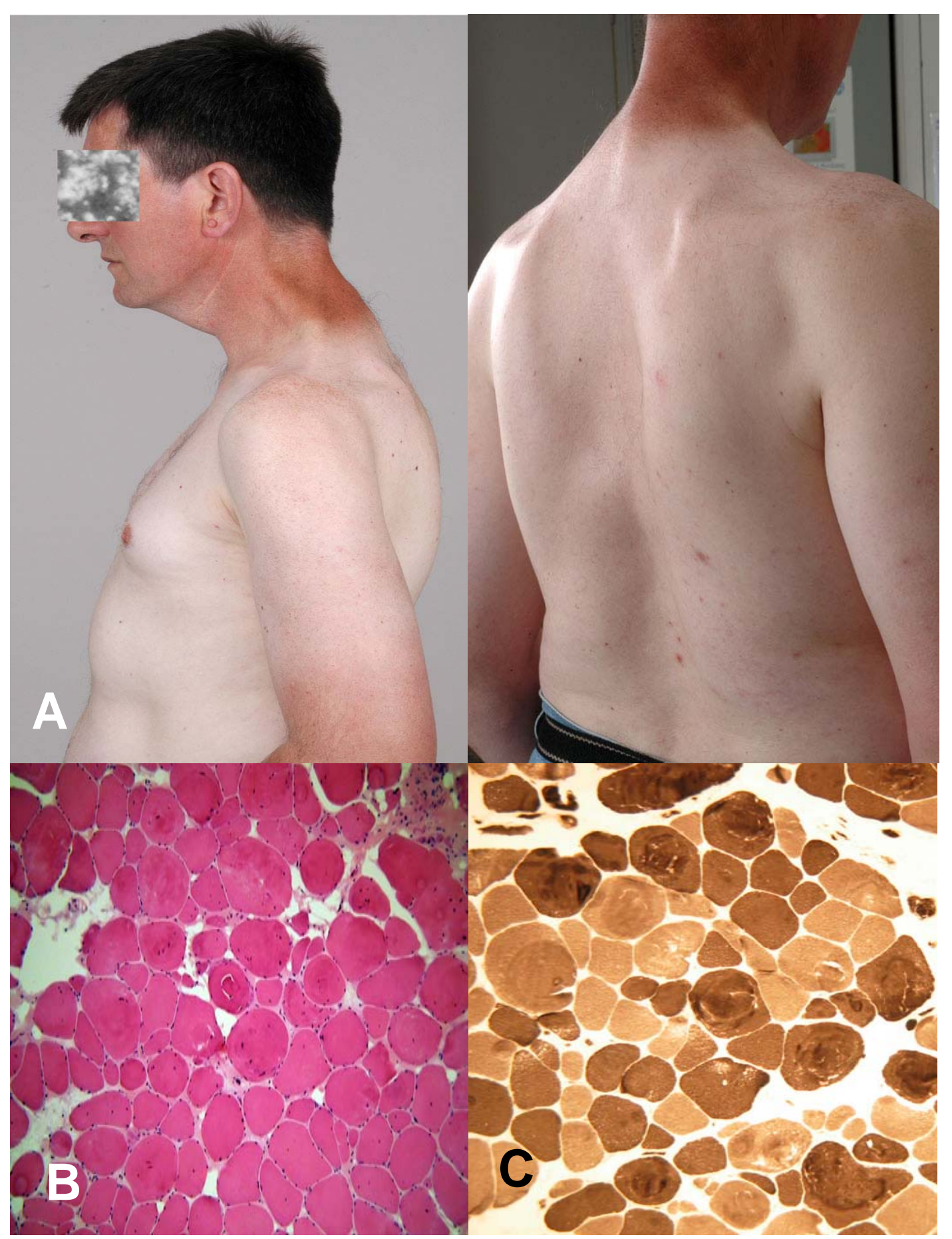

